\title{
Inhaltsübersicht.
}

\section{Indogermanische Familie.}

Einleitang. . . . . . . . . . . . . . . . . . . . . . 1

I. Indische Religionen.

Einleitung . . . . . . . . . . . . . . . 4

1. Die Religion der vedischen Zeit.

a) Die vedischen Götter . . . . . . . . . . . . . . . . 12

b) Das Verhăltnis der Menschen zu den vedischen Göttern . 29

2. Der ältere Brahmanismus.

a) Die Theologie des Brahmanismus. . . . . . . . . . . 36

b) Religiöses Leben im Brahmanismus . . . . . . . . 45

c) Soziales Leben in Brahmanismus. . . . . . . . . . 63

3. Der Buddhismus.

a) Leben und Wirken des Buddha . . . . . . . . . . 59

b) Grundzüge der Lehre des Buddha . . . . . . . . . 70

c) Weitere Ausgestaltung der Lehre und des Gemeindelebens 78

a) Dharma . . . . . . . . . . . . . . . . . . 79

B) Vinaja . . . . . . . . . . . . . . . . . . . 84

d) Spattere Entwicklung und Ausbreitung des Buddhismus . 90

c) Buddhismus und Christentum . . . . . . . . . . . . 99

4. Der Dschainismus . . . . . . . . . . . . . . . . 106

5. Der Hinduismus.

a) Allgemeine Charakteristik . . . . . . . . . . . . 111

b) Die drei Hauptgötter und die Religionen des Hinduisinus 114

c) Religiöse Sitten und Gebrăuche des Hinduismus . . . , 126

d) Die Sikhs . . . . . . . . . . . . . . . . . . . . . . . . 129

e) Brahma Samadsch und Arja.Samadsch . . . . . . . . 136

\section{Die Parsische Religion.}

Einleitung . . . . . . . . . . . . . . . . . . . . 140

1. Ahuramazda und Angramainju. . . . . . . . . . . . 154

2. Der Kampf zwischen Ahuramazda und Angramainju . . . 164

3. Kultus und Frömmigkeit . . . . . . . . . . . . . . 170

4. Theologische Kritik des Parsismus . . . . . . . . . . 175

5. Der spătere Mithradienst im Morgen- und Abendland . . . 180

6. Die heutigen Parsi . . . . . . . . . . . . . . . . 184 
III. Die Hellenische Religion.

Einleitung . . . . . . . . . . . . . . . . . . . 187

1. Die historische Entwicklung der griechischen Religion.

a) Vorhomerische Zeit . . . . . : . . . . . . . . 197

b) Homerische Zeit . . . . . . . . . . . . . . . . . 201

c) Die Hesiodische Dichtung . . . . . . . . . . . . 207

d) Blütezeit des hellenischen Vollistuıns. . . . . . . . 208

e) Hellenistische Zeit . . . . . . . . . . . . . . . . . . . . 212

2. Die hellenische Götterwelt. . . . . . . . . . . . . 214

3. Heroen, Theogonie, Schicksal, Unterwelt . . . . . . . 236

4. Kultus, Frömmigkeit, Sitte . . . . . . . . . . . . 247

IV. Die Römische Religion.

Einleitung . . . . . . . . . . . . . . . . . . . . 259

1. Die historische Entwickiung der römischen Religion.

a) Die Zeit der landlichen Gottheiten . . . . . . . . 265

b) Die erste Zeit des römischen Gemeinwesens (Numa) . 266

c) Von den Tarquiniern bis zum zweiten punischen Krieg 268

d) Vom zweiten punischen Kriege bis zum Ende der Republik 271

e) Unter dem Kaisertum . . . . . . . . . . . . . 276

2. Die Götter und Genien der Röner . . . . . . . . 280

3. Kultus und Sitte . . . . . . . . . . . . . . . 294

V. Die Religion der Kelten . . . . . . . . . . . . . . . . 312

VI. Die Religion der Germunen.

1. Die alte Religion Germaniens.

Einleitung . . . . . . . . . . . . . . . . . . . 316

a) Götter und Geister der alten Germanen . . . . . . 320

b) Kultus und Brauch . . . . . . . . . . . . . . 326

2. Die nordische Religion.

Vorbemerkung über das nordische Schrifttum . . . . . 330

a) Die nordischen Götter . . . . . . . . . . . . . 332

b) Die nordische Weltanschauung . . . . . . . . . . . 339

c) Moderne Kritik der nordischen Mythologie . . . . . $\mathbf{3 4 3}$

d) Kultus und Brauch bei den nordischen Germunen . . 346

VII. Religion der Slaven . . . . . . . . . . . . . . . . 349

\section{E. Afrikanische Gruppe.}

Einleitung: Die Neger Afrikas . . . . . . . . . . . . . . 356

1. Die Vorstellung des Himmelsgottes . . . . . . . . . . . 363

2. Geisterglauben und Fetischismus bei den uördlichen Negervölkern $\mathbf{3 7 0}$

3. Kultus und religiöser Brauch . . . . . . . . . . . . . 378

\section{F. Amerikanische Gruppe.}

I. Die wilden Indianer.

Einleitung . . . . . . . . . . . . . . . . . . 388

Die Religion der wilden Indianer . . . . . . . . . . , 393 
II. Die Hexikaner.

Einleitung . . . . . . . . . . . . . . . . . . . 400

Die Religion der Mexikaner . . . . . . . . . . . . . 403

III. Die Peruaner.

Einleitung . . . . . . . . . . . . . . . . . . . . 419

Die Religion der Peruaner . . . . . . . . . . . . . 421

G. Ozeanische Gruppe.

Einleitung . . . . . . . . . . . . . . . . . . . . . 431

1. Die Australier und Tasmanier . . . . . . . . . . . . . 431

2. Die Melanesier . . . . . . . . . . . . . . . . . . . 435

3. Die Mikronesier . . . . . . . . . . . . . . . . . . 438

4. Die Polynesier . . . . . . . . . . . . . . . . . . . 440

Schlussbemerkungen.

1. Allgemeinheit der Religion . . . . . . . . . . . . . . 454

2. I)ie Frage nach der frühesten Gestalt der lieligion. . . . . 4引ا;

3. Verhältnis der Völkerreligionen zum Christentum . . . . . 463 